\title{
Milk Production, Conjugated Linoleic Acid Content, and In Vitro Ruminal Fermentation in Response to High Levels of Soybean Oil in Dairy Ewe Diet
}

\author{
P. Gómez-Cortés, ${ }^{*}$ P. Frutos, † A. R. Mantecón, $†$ M. Juárez, ${ }^{*}$ M. A. de la Fuente, ${ }^{\star 1}$ and G. Hervás† \\ *Instituto del Frío (CSIC), José Antonio Novais 10, Ciudad Universitaria, s/n 28040 Madrid, Spain \\ †Estación Agrícola Experimental (CSIC), Finca Marzanas, 24346 Grulleros, León, Spain
}

\section{ABSTRACT}

Feeding vegetable oils rich in linoleic acid has been demonstrated to be an effective strategy to enrich milk with conjugated linoleic acid (CLA). However, high amounts of vegetable oil in the diet in free form could adversely affect animal performance, mainly in sheep. The aim of this work was to improve the ewe milk fatty acid profile by increasing potentially healthy acids such as CLA without any detrimental effects on milk production and ruminal fermentation with soybean oil (SBO) diet supplementation. Twenty-four ewes were assigned to 2 treatments and fed 2 diets (control or supplemented with $6 \%$ of SBO; 2 lots of 6 animals per treatment) and fed ad libitum for $4 \mathrm{wk}$. The forage:concentrate ratio was 20:80. Batch cultures of rumen microorganisms were used to study in vitro rumen fermentation. Changes in fatty acid profile were characterized as a reduction in $\mathrm{C} 6: 0$ to $\mathrm{C} 16: 0$ at the expense of an increase in C18:0, C18:1 isomers, and CLA concentrations. Proportions of milk CLA and trans-11 C18:1 (vaccenic acid) went from 1.04 to 3.44 and 2.08 to $6.20 \mathrm{~g} / 100 \mathrm{~g}$ of total fatty acids, respectively. However, the SBO diet also increased trans-10 C18:1 and other trans $\mathrm{C} 18: 1$ content. No significant decreases were found in the treatments for dry matter intake and milk production. The notable increases in trans-10, cis-12 and trans-9, cis-11 were not accompanied by fat level decreases in ewe milk. Concerning in vitro ruminal fermentation, no significant differences were found in the extent and rate of gas production, effective degradability, in vitro true digestibility, and volatile fatty acid production. The results demonstrate that dairy sheep milk CLA content can be substantially increased (more than 3 -fold) by adding high levels of SBO in the diet as free oil, without any negative effects on animal performance.

Received September 25, 2007.

Accepted December 12, 2007.

${ }^{1}$ Corresponding author: mafl@if.csic.es
Key words: conjugated linoleic acid, ewe, milk, soybean oil

\section{INTRODUCTION}

There is much current interest in adding value to milk and dairy products by increasing the levels of specific fatty acids (FA), which are thought to be beneficial for human health such as conjugated linoleic acid (CLA). Given that CLA is produced naturally in ruminant animals, a rational approach to increase milk fat CLA levels may be to increase the dietary intake of unsaturated FA, the substrate for CLA synthesis.

Altering the diets and feeding practices of ruminants will affect the CLA and trans C18:1 isomer composition of milk fats. Supplementation with plant oils and seeds such as cottonseed, soybean, sunflower, or safflower, with a high linoleic acid content, has been confirmed as an effective nutritional strategy to enrich ruminant milk fat in cis-9, trans-11 C18:2 (rumenic acid, RA), the biologically most active CLA isomer and in trans11 C18:1 (vaccenic acid, VA), its precursor in the mammary gland (Palmquist et al., 2005).

Results from the literature focus primarily on dairy cows or goats, and information on ewes is still scarce. Compared with cow and goat milk, sheep milk is characterized by its higher total solids and fat content, which makes it ideal for cheese production. Cow milk fat content is also sharply reduced by administering unprotected, unsaturated vegetable oils, whereas the situation is less clear in goat (Chilliard et al., 2003) and ewe (Pulina et al., 2006) milk.

The addition of plant oils in the form of intact oily seeds is less effective than free oil to increase milk VA and RA content (Dhiman et al., 2000), but the use of free oil in high doses in the diet is not recommended in ruminants (Garnsworthy, 1997), because it might inhibit rumen microbial activity and affect milk production and composition (Jenkins, 1993). In ewe diets, the addition of vegetable oils (6 to $7 \%$ linseed oil) has been reported to affect ruminal fermentation, with a de- 
crease in feed cell wall digestion (Broudiscou et al., 1994).

Recently, Antongiovanni et al. (2004) enhanced CLA levels in ewe milk fat by introducing soybean oil (SBO) into the diet, and Kucuk et al. (2001) reported a high duodenal flow of VA in ewes fed a high-concentrate diet supplemented with high levels of linoleic acid. However, data on milk production or composition together with milk FA profile are more scarce (Mele et al., 2006). The aim of the present work was to investigate whether the supplementation of a high-concentrate diet with high levels of SBO (6\% in DM) would be a suitable strategy to enhance RA and VA content in ewe milk fat without detrimentally affecting milk production and rumen fermentation.

\section{MATERIALS AND METHODS}

\section{Animals and Experimental Diets}

Twenty-four primiparous Spanish Assaf ewes (BW: $77.3 \pm 1.88 \mathrm{~kg}$ ) in midlactation (at wk 18 of lactation at the beginning of the experiment) were used. The ewes were distributed in 4 lots of 6 animals, balanced for milk yield and live weight, and allocated at random to 2 experimental treatments: 2 lots were used as the control (control), and the other 2 received the diet supplemented with SBO.

The ewes were milked at about 0830 and 1830 in a $1 \times 12$ stall-milking parlor (DeLaval, Madrid, Spain). The experiment lasted for a total of 4 wk (from wk 18 to 21 of lactation) and was carried out in accordance with the Spanish Royal Decree 1201/2005 for the protection of animals used for experimental purposes.

The diets consisted of a TMR, including molasses to avoid selection of dietary components, based on alfalfa hay and concentrate (forage:concentrate ratio 20:80) supplemented with 0 (control) or $60 \mathrm{~g}$ of SBO/kg of DM. The ingredients and chemical composition of the experimental diets are given in Table 1 . For the first week of the trial (adaptation week), all the animals received the control diet. Fresh diets were offered daily ad libitum at about 0900 and $1900 \mathrm{~h}$.

\section{Measurements, Sample Collection, and Chemical Analysis}

The intake was recorded weekly for each experimental lot. Samples of offered and refused diets were collected weekly, stored at $-30^{\circ} \mathrm{C}$, and then freeze-dried. Procedures described by the AOAC (2006) were used to determine the DM, OM, Kjeldahl N, and ether extract. Crude protein was calculated as $\mathrm{N} \times 6.25$. Neutral detergent fiber and $\mathrm{ADF}$ were determined by the methods described by Van Soest et al. (1991) and Goering and
Table 1. Ingredients and chemical composition of experimental diets

\begin{tabular}{lrr}
\hline & \multicolumn{2}{c}{ Diet } \\
\cline { 2 - 3 } Item & Control & SBO \\
\hline Ingredients, g/kg of DM & & \\
Dehydrated alfalfa hay & 200.0 & 188.0 \\
Beet pulp & 90.0 & 84.6 \\
Corn & 250.0 & 235.0 \\
Barley & 150.0 & 141.0 \\
Soybean meal & 200.0 & 188.0 \\
Soybean oil & 1 & 60.0 \\
Molasses & 0.0 & 61.1 \\
Salts & 65.0 & 37.6 \\
Minerals and vitamins & 40.0 & 4.7 \\
Composition, g/kg of DM & 5.0 & 107.1 \\
OM & & 164.0 \\
CP & 114.0 & 221.9 \\
NDF & 176.1 & 118.3 \\
ADF & 226.2 & 77.3 \\
EE & 119.9 & 24.7 \\
\hline
\end{tabular}

${ }^{1}$ Soybean oil (SBO) contained (\% of total fatty acid methyl esters) C16:0 (12.7), C18:0 (4.1), C18:1 (26.4), C18:2 (50.9), C18:3 (5.0), C20:0 (0.4), C22:0 (0.5), and C24:0 (0.1).

${ }^{2} \mathrm{EE}=$ ether extract.

Van Soest (1970), adding sodium sulfite to the solution. The NDF was assayed with $\alpha$-amylase.

Individual milk production was recorded weekly. Milk samples for the determination of fat, protein, and total solids concentrations were also collected weekly from each animal. Fat, protein, and total solids concentrations were determined (AOAC, 2006), in samples treated with natamycin, by infrared spectrophotometry using a Milko-Scan 255 A/S N (Foss Electric, Hillerød, Denmark).

Fatty acid composition was determined in untreated milk samples from each experimental lot, composited according to individual milk production. Milk fat was extracted following the Luna et al. (2005b) procedure. Fatty acid methyl esters were prepared by base-catalyzed methanolysis of the glycerides according to ISOIDF (2002). Analysis of FA methyl esters was performed on a gas-liquid chromatograph (Agilent $6890 \mathrm{~N}$ Network System, Palo Alto, CA) with an auto injector onto a CP-Sil 88 fused silica capillary column $(100 \mathrm{~m} \times 0.25$ $\mathrm{mm}$, Varian, Middelburg, the Netherlands) according to Luna et al. (2008).

Silver ion HPLC $\left(\mathbf{A g}^{+}\right.$-HPLC) separation of CLA methyl esters was carried out using an HPLC (Shimadzu, model SPE-MA10AVP, Kyoto, Japan) equipped with a diode array detector operated at $233 \mathrm{~nm}$. Three ChromSpher 5 Lipid analytical silver-impregnated columns $(250 \mathrm{~mm} \times 4.6 \mathrm{~mm}$ i.d. stainless steel; $5 \mu \mathrm{m}$ particle size; Varian) were used in series. The mobile phase was $0.1 \%$ acetonitrile and $0.5 \%$ diethyl ether in hexane and was operated isocratically at a flow rate of $1 \mathrm{~mL} /$ min. The sum $\mathrm{Ag}^{+}-\mathrm{HPLC}$ areas for 7-9, 8-10, and 9-11 
positional isomers (cis-trans plus trans-cis) were used for comparison with the peak area of these 3 isomers from the GC chromatogram. The amounts of the other CLA isomers were calculated from their $\mathrm{Ag}^{+}-\mathrm{HPLC}$ areas relative to the area of the main isomer 9-11 as described Collomb et al. (2004). The results were expressed as absolute values in milligrams per gram of total FA.

\section{In Vitro Ruminal Fermentation}

Differences between diets in rumen fermentation were studied using a modification of the gas production technique of Theodorou et al. (1994), adapted by Mauricio et al. (1999).

Two rumen fluid inocula were collected from 4 ruminally cannulated ewes fed the control diet ad libitum. Six samples (3 bottles/inoculum $\times 2$ inocula) of each $\operatorname{diet}$ (control and SBO; $\approx 500 \mathrm{mg}$ ) were incubated in 125$\mathrm{mL}$ serum bottles at $39^{\circ} \mathrm{C}$ with $10 \mathrm{~mL}$ of rumen fluid and $40 \mathrm{~mL}$ of phosphate-bicarbonate buffer (Goering and Van Soest, 1970). The rate and extent of gas production were determined by measuring head-space gas pressure at $2,4,6,9,12,16,21,27,35,48,72$, and 96 $\mathrm{h}$ postinoculation. Pressure values, corrected for the quantity of $\mathrm{OM}$ incubated and gas released from blanks (i.e., without substrate), were used to generate gas volume estimates using a predictive equation (Hervás et al., 2005). In vitro OM disappearance (g/kg) after $96 \mathrm{~h}$ of incubation was estimated by filtering residues using preweighed sintered glass crucibles (100 to $160 \mu \mathrm{m}$; Pyrex, Stone, UK) and ashing at $550^{\circ} \mathrm{C}$ for $6 \mathrm{~h}$.

Gas production data were fitted to an exponential model (SAS Institute, 1999) to provide parameters describing gas release in terms of cumulative gas production $(A, \mathrm{~mL}$ of gas/g of $\mathrm{OM}$ incubated) and fractional fermentation rate $(c, / \mathrm{h})$. Average fermentation rate (AFR, $\mathrm{mL}$ of gas/h) and extent of degradation in the rumen $(\mathrm{ED}, \mathrm{g} / \mathrm{kg}$ of $\mathrm{DM})$ were estimated assuming a rumen particulate outflow $(k p, / \mathrm{h})$ of 0.042 , according to the following equations:

$$
\begin{gathered}
\mathrm{ED}=\left[(c \times \mathrm{DMD}) /\left(c+k_{p}\right)\right] \times \mathrm{e}^{-\mathrm{kp}} \\
\mathrm{AFR}=(A \times c) /[(2 \times \ln 2)+c],
\end{gathered}
$$

where DMD = DM disappearance after $96 \mathrm{~h}$ of incubation.

For each diet, 6 more samples (i.e., 3 bottles/inoculum $\times 2$ inocula) were incubated for $24 \mathrm{~h}$. Immediately afterwards, the $\mathrm{pH}$ was measured, and samples were collected for $\mathrm{NH}_{3}-\mathrm{N}$ and VFA analysis, as described by Frutos et al. (2004). The amount of $\mathrm{CH}_{4}$ produced was calculated according to the following stoichiometry equation: $\mathrm{CH}_{4}=0.5 \times$ acetate $-0.25 \times$ propionate +0.5 $\times$ butyrate.

\section{Statistical Analyses}

Data on DM intake, milk production, and composition as well as FA composition and CLA profile were analyzed by repeated measurement analysis (Wang and Goonewardene, 2004), using the MIXED procedure of the SAS program (SAS Institute, 1999) and assuming a compound symmetric structure on the basis of Schwarz's Bayesian information model fit criteria. The statistical model included the fixed effects of diet (D), time $(\mathrm{T})$, their interaction $(\mathrm{D} \times \mathrm{T})$, and the initial record measured at $0 \mathrm{wk}$ (covariate). For all data collected either individually (milk production and composition) or per lot (DM intake, FA composition, and CLA profile), the lot was nested within the diet to contrast the effect of the SBO supplementation. One-way ANOVA (SAS, 1999) was applied to the data from the in vitro trial. Least square means (adjusted for the covariance) are reported throughout, and significance was considered at $P<0.05$. Differences of $P>0.05$ to $P<0.10$ are discussed as trends.

\section{RESULTS AND DISCUSSION}

\section{Intake and Lactation Performance}

Table 2 shows the milk yield, DM intake, milk composition, and protein and fat yield results for each experimental diet. The addition of 6\% of SBO did not alter $(P>0.10)$ either the feed intake (on average $2.20 \mathrm{~kg} / \mathrm{d}$ ) or the milk production (on average $1.72 \mathrm{~kg} / \mathrm{d}$ ). Feed intake significantly decreased with time $(P<0.01)$ in both treatments (control and SBO; $P>0.10$ for the interaction $\mathrm{D} \times \mathrm{T}$ ), with values ranging from $2.33 \mathrm{~kg} / \mathrm{d}$ in the first experimental week to $2.16 \mathrm{~kg} / \mathrm{d}$ in the last one. No significant changes $(P>0.10)$ were observed with the SBO supplementation on the daily fat, protein, or TS production (Table 2).

These results contrast with most studies conducted on dairy cows, where oil supplementation seems to reduce feed intake, milk production, and milk fat content (Chilliard et al., 2003; Griinari and Bauman, 2006). Similarly, other authors have found that the inclusion of oils or fats in the diet may decrease milk fat content and milk production (Griinari et al., 1998; Griinari and Bauman, 2006). Dietary composition may have had a great effect in these differences, because the current study was performed with a very high concentrate diet (see Table 1), whereas the concentrate:forage ratio reported in most dairy cows studies is much lower.

Coinciding with most of the earlier studies on sheep (Chilliard et al., 2003; Pulina et al., 2006; Zhang et al., 
Table 2. Effects of sheep diet supplementation with 6\% soybean oil (SBO) on DM intake, milk yield, and milk composition

\begin{tabular}{|c|c|c|c|c|c|c|}
\hline \multirow[b]{2}{*}{ Item } & \multicolumn{2}{|c|}{ Treatment $^{1}$} & \multirow[b]{2}{*}{ SEM } & \multicolumn{3}{|c|}{$P<<^{2}$} \\
\hline & Control & SBO & & $\mathrm{D}$ & $\mathrm{T}$ & $\mathrm{D} \times \mathrm{T}$ \\
\hline DM intake $(\mathrm{kg} / \mathrm{d})$ & 2.07 & 2.33 & 0.078 & 0.26 & $<0.01$ & 0.20 \\
\hline \multicolumn{7}{|l|}{ Yield (g/d) } \\
\hline Milk & 1,703 & 1,728 & 43.9 & 0.89 & 0.13 & 0.22 \\
\hline Fat & 90.5 & 94.1 & 0.97 & 0.37 & 0.23 & 0.15 \\
\hline Protein & 84.3 & 81.0 & 1.91 & 0.66 & 0.36 & 0.31 \\
\hline TS & 278.9 & 273.6 & 4.76 & 0.77 & 0.12 & 0.13 \\
\hline \multicolumn{7}{|l|}{ Composition (\%) } \\
\hline Fat & 5.40 & 5.72 & 0.122 & 0.52 & 0.97 & 0.34 \\
\hline Protein & 5.15 & 4.61 & 0.108 & 0.10 & 0.45 & 0.93 \\
\hline TS & 16.21 & 16.39 & 0.138 & 0.74 & 0.90 & 0.16 \\
\hline
\end{tabular}

${ }^{1}$ Refers to diets containing 0 (control) or $60 \mathrm{~g}$ of SBO/kg of DM.

${ }^{2}$ Probability of significant effects due to diet supplementation with SBO (D), time on diet (T), and their interaction $(\mathrm{D} \times \mathrm{T})$.

2006), the inclusion of SBO tended to decrease the milk protein content (approximately $10 \% ; P<0.10$ ). It could be argued that this decrease is the result of the low amount of AA in the mammary gland necessary to accompany increased milk production resulting from lipid supplementation (Gaynor et al., 1994). However, this argument is dismissed, because milk production remained unchanged (Table 2). Another possible explanation for the lower content of proteins could be related to changes in the metabolism of insulin or glucose in the mammary gland (Dhiman et al., 1995) related to lipid supplementation.

\section{Milk FA Composition}

Table 3 shows the FA profile of the milk fat of ewes fed with the control diet or the diet supplemented with SBO. As can be seen, there are large differences in composition due to the type of feed. The effects of time are, however, more limited.

The inclusion of SBO in the diet produced significant increases in 18-C atom FA content, at the expense of a decrease in $\mathrm{C} 6: 0$ to $\mathrm{C} 16: 0$ saturated FA concentration (Table 3). The reasons for the decrease observed in C10:0, C12:0, C14:0, and C16:0 content could be physiological. Long-chain 18-C atom FA are powerful inhibitors of the de novo synthesis of FA in the mammary gland, because they have an inhibitory effect on acetylcoenzyme A carboxylase (Chilliard et al., 2003). This enzyme greatly affects the lipogenesis of milk fat in the udder of ruminants, because it contributes via malonylcoenzyme A to the lengthening of the saturated FA hydrocarbon chains from the acetate molecules that are generated during digestion in the rumen. Significant increases $(P<0.05)$ of butyric acid $(\mathrm{C} 4: 0)$ in diets enriched with SBO could be explained by the fact that this FA could be partially synthesised by metabolic routes not dependent on acetyl-coenzyme A carboxylase, evidence already reported in cows and goats (Chilliard et al. 2003). As a result of the higher levels of unsaturated FA and lower levels of the medium- and long-chain saturated ones, a significant effect $(P<0.05)$ was observed on the atherogenicity index value [ $\mathrm{C} 12$ $+4 \times \mathrm{C} 14+\mathrm{C} 16) /($ monounsaturated $\mathrm{FA}+$ polyunsaturated FA)] in milk from animals fed diets supplemented with SBO (Table 3). This reduction would be positive from a nutritional point of view.

The increased C18:0 levels in ewe milk supplemented with SBO $(P<0.10)$ would be the result of total rumen biohydrogenation of part of the C18:2 of the diet, whereas the increases $(P<0.05)$ observed in the oleic acid (cis-9 C18:1) content could be the consequence, on the one hand, of the action of the $\Delta^{9}$-desaturase enzyme on the mammary gland on a part of this C18:0 generated in the rumen and, on the other, of its greater presence in the supplemented diet (Table 1). Regarding the rest of the 18-C monounsaturated FA, both trans and cis, the intermediaries in the different rumen biohydrogenation processes, most increased their levels with the supplemented diet. The largest increases were for VA and trans-10 C18:1, which reached a percentage higher than $6 \%$ at the end of the study (Figure 1).

The abundance of intermediaries in the biohydrogenation processes in milk is characteristic of diets rich in polyunsaturated fatty acids (PUFA) administered in free form. Dhiman et al. (2000) observed that the use of free oils instead of intact seeds was an efficient procedure for increasing the content of these intermediaries in cow milk. Fatty acids would be released more slowly when they were inside the seeds, but once free in the rumen, they would be hydrogenated in a greater extension until they were converted to estearic acid, thus limiting the presence of unsaturated intermediaries in ruminal liquid. Diets with high doses of free oil rich 
Table 3. Effects of sheep diet supplementation with $6 \%$ soybean oil (SBO) on milk fatty acid profile (g/100 $\mathrm{g}$ of fatty acid methyl esters)

\begin{tabular}{|c|c|c|c|c|c|c|}
\hline \multirow[b]{2}{*}{ Item } & \multicolumn{2}{|c|}{ Treatment $^{1}$} & \multirow[b]{2}{*}{ SEM } & \multicolumn{3}{|c|}{$P<^{2}$} \\
\hline & Control & SBO & & $\mathrm{D}$ & $\mathrm{T}$ & $\mathrm{D} \times \mathrm{T}$ \\
\hline $\mathrm{C} 4: 0$ & 3.51 & 4.27 & 0.088 & $<0.01$ & 0.65 & 0.04 \\
\hline $\mathrm{C} 6: 0$ & 3.27 & 2.28 & 0.187 & 0.02 & 0.18 & 0.60 \\
\hline $\mathrm{C} 8: 0$ & 2.90 & 1.98 & 0.280 & 0.07 & 0.19 & 0.59 \\
\hline $\mathrm{C} 10: 0$ & 9.64 & 5.15 & 0.312 & $<0.01$ & 0.22 & 0.22 \\
\hline C10:1 & 0.48 & 0.20 & 0.033 & $<0.01$ & 0.46 & 0.59 \\
\hline C12:0 & 5.09 & 2.95 & 0.144 & $<0.01$ & 0.97 & 0.26 \\
\hline $\mathrm{C} 13: 0$ anteiso & 0.06 & 0.03 & 0.003 & $<0.01$ & 0.13 & 0.83 \\
\hline C13:0 & 0.19 & 0.09 & 0.013 & $<0.01$ & 0.48 & 0.28 \\
\hline $\mathrm{C} 14: 0$ iso & 0.06 & 0.04 & 0.011 & 0.27 & 0.67 & 0.94 \\
\hline C14:0 & 12.35 & 8.48 & 1.645 & 0.16 & 0.67 & 0.91 \\
\hline $\mathrm{C} 15: 0$ iso & 0.15 & 0.14 & 0.007 & 0.35 & 0.04 & 0.10 \\
\hline $\mathrm{C} 15: 0$ anteiso & 0.39 & 0.26 & 0.021 & $<0.01$ & 0.55 & 0.74 \\
\hline C14:1 & 0.29 & 0.15 & 0.011 & $<0.01$ & 0.08 & 0.76 \\
\hline C15:0 & 0.91 & 0.50 & 0.019 & $<0.01$ & $<0.01$ & 0.05 \\
\hline $\mathrm{C} 16: 0$ iso & 0.25 & 0.15 & 0.006 & $<0.01$ & 0.17 & 0.39 \\
\hline $\mathrm{C} 16: 0$ & 27.96 & 22.29 & 0.497 & $<0.01$ & 0.19 & 0.71 \\
\hline trans $-9 \mathrm{C} 16: 1+\mathrm{C} 17: 0$ iso & 0.57 & 1.10 & 0.071 & $<0.01$ & 0.16 & 0.54 \\
\hline cis-7 C16:1 & 0.26 & 0.21 & 0.009 & $<0.01$ & 0.33 & 0.99 \\
\hline cis-9 C16:1 + C17:0 anteiso & 1.91 & 1.12 & 0.041 & $<0.01$ & 0.02 & 0.07 \\
\hline C17:0 & 0.62 & 0.34 & 0.013 & $<0.01$ & 0.48 & 0.22 \\
\hline $\mathrm{C} 17: 1$ & 0.17 & 0.09 & 0.004 & $<0.01$ & 0.05 & 0.24 \\
\hline C18:0 & 4.86 & 7.60 & 0.875 & 0.08 & 0.74 & 0.81 \\
\hline trans $6+7+8$ C18: 1 & 0.46 & 0.83 & 0.075 & 0.02 & 0.31 & 0.18 \\
\hline trans-9 C18:1 & 0.44 & 0.65 & 0.073 & 0.10 & 0.08 & 0.04 \\
\hline trans-10 C18:1 & 1.90 & 6.06 & 2.114 & 0.23 & 0.12 & 0.11 \\
\hline trans-11 C18:1 & 2.08 & 6.20 & 0.656 & $<0.01$ & $<0.01$ & $<0.01$ \\
\hline trans -12 C18:1 & 0.42 & 0.68 & 0.037 & $<0.01$ & 0.51 & 0.76 \\
\hline$c i s-9$ C18:1 & 12.18 & 15.31 & 0.706 & 0.03 & 0.59 & 0.33 \\
\hline trans $-15+$ cis-11 C18:1 & 0.57 & 0.84 & 0.046 & $<0.01$ & 0.60 & 0.65 \\
\hline cis-12 C18:1 & 0.33 & 0.51 & 0.091 & 0.23 & 0.56 & 0.73 \\
\hline cis-13 C18:1 & 0.07 & 0.16 & 0.010 & $<0.01$ & $<0.01$ & $<0.01$ \\
\hline trans $-16+$ cis-14 C18:1 & 0.32 & 0.31 & 0.025 & 0.77 & 0.60 & 0.32 \\
\hline trans -9, trans $-12+$ other trans-trans $\mathrm{C} 18: 2$ & 0.44 & 0.56 & 0.034 & 0.06 & 0.10 & 0.31 \\
\hline cis -9, trans -12 + other cis/trans $\mathrm{C} 18: 2$ & 0.27 & 0.27 & 0.030 & 0.86 & 0.55 & 0.96 \\
\hline trans -9, cis-12 C18:2 & 0.04 & 0.06 & 0.006 & 0.11 & 0.62 & 0.37 \\
\hline trans -11 , cis-15 C18:2 & $<0.01$ & 0.94 & 0.631 & 0.20 & 0.48 & 0.53 \\
\hline cis-9, cis-12 C18:2 & 2.70 & 3.46 & 0.158 & 0.02 & 0.08 & 0.91 \\
\hline $\mathrm{C} 20: 0$ & 0.13 & 0.18 & 0.007 & $<0.01$ & 0.52 & 0.77 \\
\hline C20:1 & 0.08 & 0.03 & 0.004 & $<0.01$ & 0.39 & 0.34 \\
\hline C21:0 & 0.04 & 0.03 & 0.001 & $<0.01$ & 0.40 & 0.23 \\
\hline C18:3 & 0.35 & 0.46 & 0.029 & 0.04 & 0.99 & 0.55 \\
\hline cis-9, trans-11 C18:2 & 1.04 & 3.44 & 0.233 & $<0.01$ & 0.09 & 0.18 \\
\hline trans -9, cis-11 C18:2 & 0.03 & 0.09 & 0.014 & 0.03 & 0.03 & 0.03 \\
\hline trans -10, cis -12 C18:2 & 0.01 & 0.08 & 0.012 & $<0.01$ & 0.17 & 0.11 \\
\hline trans-11, cis-13 C18:2 & 0.03 & 0.02 & 0.001 & $<0.01$ & 0.10 & 0.47 \\
\hline trans -12, trans-14 C18:2 & 0.01 & 0.02 & 0.004 & 0.53 & 0.27 & 0.67 \\
\hline trans- 11 , trans-13 C18:2 & 0.03 & 0.02 & 0.001 & $<0.01$ & 0.10 & 0.47 \\
\hline Other trans-trans CLA & 0.02 & 0.04 & 0.010 & 0.16 & 0.42 & 0.45 \\
\hline $\mathrm{AI}^{3}$ & 3.08 & 1.52 & 0.112 & $<0.01$ & 0.51 & 0.39 \\
\hline
\end{tabular}

${ }^{1}$ Refers to diets containing 0 (control) or $60 \mathrm{~g}$ of SBO/kg of DM.

${ }^{2}$ Probability of significant effects due to diet supplementation with SBO (D), time on diet (T), and their interaction $(\mathrm{D} \times \mathrm{T})$.

${ }^{3} \mathrm{AI}=$ atherogenicity index: $(\mathrm{C} 12+4 \times \mathrm{C} 14+\mathrm{C} 16) /($ monounsaturated fatty acids + polyunsaturated fatty acids).

in PUFA, however, could cause alterations in rumen metabolism with inhibition of the last stages of biohydrogenation and the consequent accumulation of trans C18:1 FA. Postrumen flows rich in different 18-C unsaturated FA have already been reported (Kucuk et al., 2001) in sheep fed supplemented diets with similar pro- portions of SBO to those assayed in this work. Furthermore, in the present study, secretion of odd and branched-chain FA in milk, often resulting from microbial FA metabolism in the rumen, tended to diminish or was significantly decreased with SBO-supplemented diets (C15:0, C15:0 anteiso, C16:0 iso, and C17:0) and 

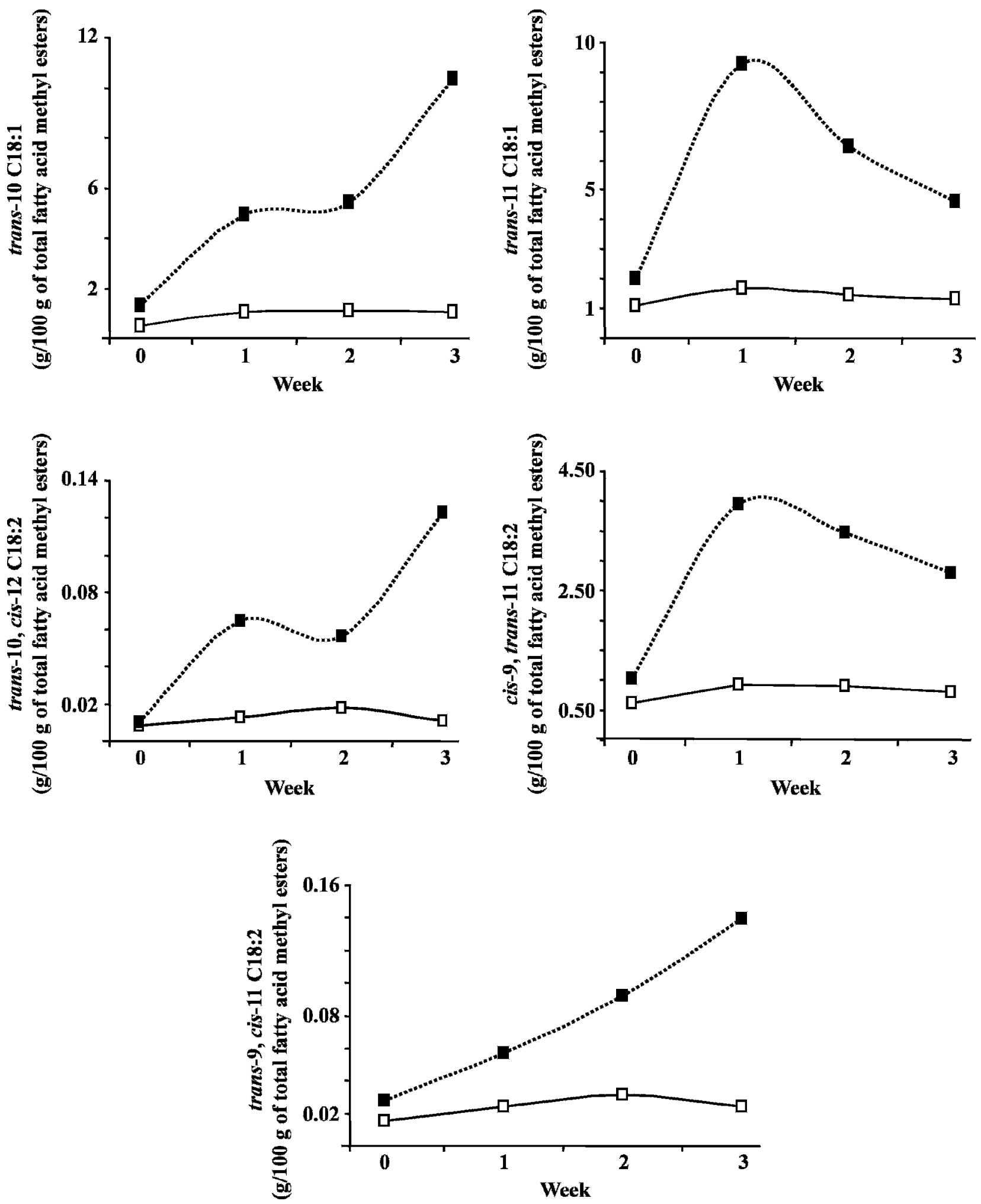

Figure 1. Temporal changes in trans-10 C18:1; trans-11 C18:1; trans-10, cis-12 conjugated linoleic acid (CLA); cis-9, trans-11 CLA; and trans-9, cis-11 CLA (g/100 g of total fatty acid methyl esters) in ewes fed diets containing 0 ( $\square$ ) or 60 ( $\square$ ) g of soybean oil/kg of DM. Values represent the mean from 2 lots of 6 animals per lot. $\mathrm{SEM}=2.114,0.656,0.012,0.233$, and 0.014 for trans-10 C18:1; trans-11 C18:1; trans10, cis-12 CLA; cis-9, trans-11 CLA; and trans-9, cis-11 CLA, respectively. 
with time (C15:0, C15:0 iso, and C15:0 anteiso), which suggests that the treatment assayed, high in concentrate and in lipids, would contribute to modify rumen metabolism.

Although VA plays a relevant role as the precursor of RA in the mammary gland and could also have beneficial effects, the effect of the intake of high amounts of other trans-monoenoic FA such as trans-10 C18:1 on human health is still not clear. In the animals fed with the control diet, the biohydrogenation pathway described by Harfoot and Hazlewood (1997) would prevail, with RA, and especially VA, as the main intermediaries. Griinari et al. (1998), however, observed that, under certain rumen conditions, linoleic acid in the diet can be isomerized first to trans-10, cis-12 C18:2 and then, by hydrogenation, to become trans-10 C18:1. The factors that displace the biohydrogenation pathways are a source rich in PUFA in the diet (Griinari et al., 1998; Loor et al., 2005) and an alteration of the rumen environment (e.g., high proportions of concentrate). The presence of high levels of concentrate in cows' (Piperova et al., 2002) and ewes' (Daniel et al., 2004) diets led to widespread increases in trans-10 C18:1 levels in the postrumen liquid to the detriment of the VA content. It has been interpreted that rations with these characteristics cause changes in the growth and proliferation of microorganisms that produce the enzymes involved in biohydrogenation processes (Palmquist et al., 2005).

The simultaneous increase in VA and trans-10 C18:1 at the start of the supplementation would indicate some equilibrium between the 2 biohydrogenation pathways of linoleic acid (Figure 1). However, the decreased VA levels and increased trans-10 C18:1 observed throughout the experiment would imply a predominance of the alternative biohydrogenation pathway. Although it is difficult to pinpoint when the displacement of this equilibrium takes place, everything suggests that it would begin to occur after $1 \mathrm{wk}$ of supplementation with SBO.

Rumenic acid content increased $(P<0.05)$ as a result of the addition of SBO to the diet and was 3 times greater than in the control diet (see Table 3 and Figure 1). Pasture-based diet (Cabiddu et al., 2005) or supplementation with linseed, sunflower, or soybean (Luna et al., 2005a, 2008; Zhang et al., 2006) have been highlighted as useful strategies to moderately increase or even double RA levels in milk, but only the use of highSBO contents trebled the initial CLA levels in ewe milk (Antongiovanni et al., 2004; Mele et al., 2006). All these results once again stress the importance of providing the lipids in free form to generate intermediaries like VA and RA more effectively in the rumen.

The evolution of the RA content throughout the experimental period is shown in Figure 1. Initially, the RA concentration increases sharply and then decreases; all this is in line with the evolution of the VA content throughout the experiment. The close correlation between RA and VA concentrations in ewe milk is wellreported (Cabiddu et al., 2005; Luna et al., 2005a; Nudda et al., 2005; Mele et al., 2006) and is due to the fact that most RA is produced in the mammary gland thanks to the activity of the $\Delta^{9}$-desaturase enzyme on the VA generated in the rumen.

\section{CLA Isomer Profile}

The increases in trans-10, cis-12 C18:2 levels throughout the period studied (Figure 1) would have to be interpreted according to the increases observed in trans-10 C18:1 content. The trans-10, cis-12 C18:2 isomer is intermediary in the alternative biohydrogenation pathway of linoleic acid proposed by Griinari et al. (1998) and, therefore, the precursor of trans-10 C18:1 in the rumen. The high proportion of trans-10 C18:1 compared with trans-10, cis-12 C18:2 in the milk of animals supplemented with SBO (Table 3 ) would indicate that enzyme equilibrium in the rumen would be greatly displaced toward the formation of this monounsaturated acid. Mele et al. (2006) also observed a significant effect in trans-10, cis-12 C18:2 content when the ewe diet was supplemented with $4 \%$ of SBO and the concentrate:forage ratio was increased.

The sharp increase in trans-9, cis-11 C18:2 levels in the milk of ewes fed diets supplemented with SBO (Figure 1, Table 3) would also be the consequence of alterations in rumen metabolism. Earlier research (Shingfield et al., 2006) have attributed notable increases of this CLA isomer in milk to changes in the biohydrogenation pathways caused by high levels of lipids in the diet. However, the metabolic pathways that would explain the generation of this isomer are not clear.

The $\mathrm{Ag}^{+}-\mathrm{HPLC}$ results for the milk studied can be seen in Table 4. The peak corresponding to the 9-11 (cistrans + trans-cis) position isomer was the most notable followed by the 7-9 (cis-trans + trans-cis) one. The other isomers determined by $\mathrm{Ag}^{+}$-HPLC were found in very low amounts and never exceeded 3\% of total CLA.

The supplementation of the diet with SBO led to a significant increase $(P<0.05)$ in most of the CLA isomers. The increases observed in trans-10, trans-12; trans-9, trans-11; trans-8, trans-10; trans- 7 , trans-9 levels; and 10-12, 9-11, 8-10, and 7-9 isomer levels (cistrans + trans-cis) (Table 4) were also reported by Collomb et al. (2004) in the milk of cows whose rations were supplemented with sunflower seed and by Mele et al. (2006) in the milk of ewes whose diets were enriched with SBO. These authors reported positive correlations between the intake of linoleic acid and that of 
Table 4. Effects of sheep diet supplementation with 6\% soybean oil (SBO) on milk conjugated linoleic acid isomers profile $(\mathrm{mg} / \mathrm{g}$ of total fatty acids)

\begin{tabular}{|c|c|c|c|c|c|c|}
\hline \multirow[b]{2}{*}{ Item } & \multicolumn{2}{|c|}{ Treatment $^{1}$} & \multirow[b]{2}{*}{ SEM } & \multicolumn{3}{|c|}{$P<^{2}$} \\
\hline & Control & SBO & & $\mathrm{D}$ & $\mathrm{T}$ & $\mathrm{D} \times \mathrm{T}$ \\
\hline \multicolumn{7}{|l|}{ trans/trans } \\
\hline 12,14 & 0.080 & 0.113 & 0.0075 & 0.03 & 0.21 & 0.93 \\
\hline 11,13 & 0.048 & 0.125 & 0.0045 & $<0.01$ & 0.20 & 0.16 \\
\hline 10,12 & 0.026 & 0.093 & 0.0022 & $<0.01$ & $<0.01$ & 0.02 \\
\hline 9,11 & 0.093 & 0.306 & 0.0424 & 0.02 & 0.06 & 0.05 \\
\hline 8,10 & 0.020 & 0.043 & 0.0022 & $<0.01$ & 0.12 & 0.05 \\
\hline 7,9 & 0.052 & 0.080 & 0.0045 & $<0.01$ & $<0.01$ & $<0.01$ \\
\hline \multicolumn{7}{|c|}{ cis/trans + trans/cis } \\
\hline 12,14 & 0.025 & 0.027 & 0.0049 & 0.72 & 0.48 & 0.91 \\
\hline trans -11, cis -13 & 0.046 & 0.077 & 0.0152 & 0.20 & 0.32 & 0.20 \\
\hline 10,12 & 0.088 & 0.608 & 0.1742 & 0.09 & 0.16 & 0.15 \\
\hline 9,11 & 8.960 & 32.434 & 2.2558 & $<0.01$ & 0.08 & 0.15 \\
\hline 8,10 & 0.234 & 0.660 & 0.0351 & $<0.01$ & 0.03 & 0.05 \\
\hline 7,9 & 1.203 & 1.508 & 0.1946 & 0.32 & 0.05 & 0.02 \\
\hline \multicolumn{7}{|l|}{ cis/cis } \\
\hline 9,11 & 0.023 & 0.034 & 0.0018 & $<0.01$ & 0.98 & 0.91 \\
\hline
\end{tabular}

${ }^{1}$ Refers to diets containing 0 (control) or $60 \mathrm{~g}$ of SBO/kg of DM.

${ }^{2}$ Probability of significant effects due to diet supplementation with SBO (D), time on diet (T), and their interaction $(\mathrm{D} \times \mathrm{T})$.

CLA isomers mentioned earlier. However, the metabolic pathways involved in these transformations are not well known.

Surprisingly, given the low $\alpha$-linolenic acid content in the intake (Table 1), trans-11, cis-13; trans-11, trans13; and trans-12,trans-14 C18:2 levels also increased notably in diets supplemented with SBO (Table 4). The increase in these isomers is usually indicative of diets enriched in $\alpha$-linolenic acid, either from the consumption of fresh pasture or the supplementation of the rations with linseed or linseed oil (Kraft et al., 2003; Loor et al., 2005; Luna et al., 2005a, 2008). In the present study, their increase, simultaneous with the increase in trans-11, cis-15 C18:2 (Table 3) would be indicative of the quantitative importance that small amounts of $\alpha$-linolenic added in free form (Table 1) would have on generating intermediaries of the biohydrogenation pathway in the rumen of this FA.

\section{In Vitro Ruminal Fermentation}

Table 5 shows the effects of diet supplementation with SBO on in vitro rumen fermentation. Final $\mathrm{pH}$ values ranged between 6.78 and 6.86 , with no differences due to the supplementation with SBO. Generally, hardly any negative effects were seen on the other parameters studied (fermentation rate, extent of degradation, etc.) from the supplementation with SBO. These results contrast with the widespread idea that PUFA can alter ruminal metabolism. Although the mechanisms involved are still not clear, the negative effects would be related to inhibitory growth and development of certain rumen microorganisms, primarily protozoa and cellulolytic bacteria (Broudiscou et al., 1994; Harfoot and Hazelwood, 1997).

In this study with batch cultures, it was observed that the supplementation with $6 \%$ SBO tended to reduce the $\mathrm{NH}_{3}$ concentration (about 11\%). This decrease could be attributed to alterations in the ruminal metabolism of N (Doreau and Ferlay, 1995), although it seems more

Table 5. Effects of diet supplementation with soybean oil (SBO) on rumen fermentation: in vitro gas production parameters $(A ; \mathrm{mL} / \mathrm{g}$ of $\mathrm{OM}$ and $c ; / \mathrm{h}$ ), average fermentation rate (AFR; $\mathrm{mL} / \mathrm{h})$, in vitro $\mathrm{OM}$ degradation (OMD; $\mathrm{g} / \mathrm{kg}$ ), extent of degradation (ED; $\mathrm{g} / \mathrm{kg}), \mathrm{NH}_{3}-\mathrm{N}$ concentration $(\mathrm{mg} / \mathrm{L})$, and VFA and $\mathrm{CH}_{4}$ production (mmol) after 24 $\mathrm{h}$ of incubation

\begin{tabular}{|c|c|c|c|c|}
\hline \multirow[b]{2}{*}{ Item } & \multicolumn{2}{|c|}{ Treatment $^{1}$} & \multirow[b]{2}{*}{ SEM } & \multirow[b]{2}{*}{$P<^{2}$} \\
\hline & Control & SBO & & \\
\hline$A$ & 351 & 358 & 3.81 & 0.30 \\
\hline$c$ & 0.080 & 0.079 & 0.0026 & 0.86 \\
\hline AFR & 18.13 & 18.35 & 0.622 & 0.83 \\
\hline OMD & 908 & 914 & 17.7 & 0.83 \\
\hline ED & 570 & 573 & 14.4 & 0.92 \\
\hline $\mathrm{NH}_{3}-\mathrm{N}$ & 473 & 419 & 8.9 & 0.06 \\
\hline Total VFA & 3.81 & 3.61 & 0.069 & 0.18 \\
\hline Acetate & 2.12 & 1.99 & 0.057 & 0.25 \\
\hline Propionate & 0.73 & 0.73 & 0.004 & 0.89 \\
\hline Butyrate & 0.69 & 0.67 & 0.012 & 0.36 \\
\hline Others $^{3}$ & 0.28 & 0.23 & 0.012 & 0.10 \\
\hline Acetate/propionate & 2.92 & 2.74 & 0.097 & 0.33 \\
\hline $\mathrm{CH}_{4}$ & 1.22 & 1.15 & 0.034 & 0.27 \\
\hline
\end{tabular}

${ }^{1}$ Refers to diets containing 0 (control) or $60 \mathrm{~g}$ of SBO/kg of DM.

${ }^{2}$ Probability of significant effects due to diet supplementation with SBO.

${ }^{3}$ Calculated as the sum of isobutyrate, isovalerate, valerate, and caproate. 
likely that the cause is linked to the low protein content in the supplemented diet (Table 1). This argument would be reinforced both by the fact that there was no significant reduction in the feed degradation parameters and the trend $(P<0.10)$ to a lower concentration of valerate and branched-chain VFA (called "others" in Table 5) coming from the deamination of some AA.

Nonetheless, it is important to mention that the assay was performed with rumen inoculum from animals that consumed the control diet, so it is possible that different results would have been obtained with inoculum from animals that consumed the diet supplemented with SBO. Our present in vivo data point to a quick adaptation of the rumen environment to the SBO supplement (most effects were observed after only 1 wk of supplementation). It is known that subtle shifts over time in rumen microbiota, in response to lipid supplements, may result in changes in rumen biohydrogenation pathways (Bauman et al., 2001). The interest of using rumen fluid inoculum from ewes fed the control diet (i.e., without any shift in the microbiota due to oil supplementation) is that differences in ruminal fermentation can be directly attributed to the effect of adding SBO.

\section{CONCLUSIONS}

The supplementation of dairy sheep diets rich in concentrate with $6 \%$ SBO was shown to be an effective nutritional strategy to improve the levels of potentially beneficial FA levels for human health, like RA and VA, and also to significantly decrease the content of most of the saturated FA and increase the oleic acid concentration. Furthermore, the presence of high contents of linoleic acid in free form in the diet of ewes did not decrease milk production or substantially change the milk composition. However, the sustainability of the response to supplementation or the presence of high trans-10 C18:1 and other trans FA contents are still not been solved.

There is also evidence from the present study that suggests that the response of the sheep to the supplementation with high concentrations of lipid supplements rich in PUFA could be different from that observed in cows. Accordingly, the generation of CLA isomers involved in milk fat depression did not significantly decrease milk fat in ewes. However, the number of works done on sheep compared with cows means that these conclusions should be treated with caution. Similarly, more studies are necessary to complement the ones that have already been done and confirm these results.

\section{ACKNOWLEDGMENTS}

This work was supported by the Ministerio de Educación y Ciencia (Spain; Research Projects AGL2005-
04760) and the Comunidad Autónoma de Madrid (Project S-0505/AGR/000153). We wish to thank N. Castañares, J. López (Estación Agrícola Experimental, CSIC), and M. V. Rodríguez-Pino (Instituto del Frío, CSIC) for their technical assistance.

\section{REFERENCES}

Antongiovanni, M., M. Mele, A. Boccioni, F. Petacchi, A. Serra, M. P. Melis, L. Cordeddu, S. Banni, and P. Secchiari. 2004. Effect of forage/concentrate ratio and oil supplementation on C18:1 and CLA isomers in milk fat from Sarda ewes. J. Anim. Feed Sci. 13(Suppl. 1):669-672.

AOAC. 2006. Official Methods of Analysis of the Association of Official Agricultural Chemists. 18th ed. 1st revision. AOAC Int., Gaithersburg, MD.

Bauman, D. E., B. A. Corl, L. H. Baumgard, and J. M. Griinari. 2001. Conjugated linoleic acid (CLA) and the dairy cow. Pages 221-250 in Recent Advances in Animal Nutrition. P. C. Garnsworthy and J. Wiseman, ed. Nottingham Univ. Press, UK.

Broudiscou, L., S. Pochet, and C. Poncet. 1994. Effect of linseed oil supplementation on feed degradation and microbial synthesis in the rumen of ciliate-free and refaunated sheep. Anim. Feed Sci. Technol. 49:189-202.

Cabiddu, A., M. Decandia, M. Addis, G. Piredda, A. Pirisi, and G. Molle. 2005. Managing Mediterranean pastures in order to enhance the level of beneficial fatty acid in sheep milk. Small Rumin. Res. 59:169-180.

Chilliard, Y., A. Ferlay, J. Rouel, and G. Lamberet. 2003. A review of nutritional and physiological factors affecting goat milk lipid synthesis and lipolysis. J. Dairy Sci. 86:1751-1770.

Collomb, M., R. Sieber, and U. Bütikofer. 2004. CLA isomers in milk fat from cows fed diets with high levels of unsaturated fatty acids. Lipids 39:355-364.

Daniel, Z. C. T. R., R. J. Wynn, A. M. Salter, and P. J. Buttery. 2004. Differing effects of forage and concentrate diets on the oleic acid and conjugated linoleic acid content of sheep tissues: The role of stearoyl-CoA desaturase. J. Anim. Sci. 82:747-758.

Dhiman, T. R., L. D. Satter, M. W. Pariza, M. P. Galli, K. Allbright, and M. X. Tolosa. 2000. Conjugated linoleic acid (CLA) content of milk from cows offered diets rich in linoleic and linolenic acid. J. Dairy Sci. 83:1016-1027.

Dhiman, T., K. Zanten, and L. Satter. 1995. Effect of dietary fat source on fatty acid composition of cow's milk. J. Sci. Food Agric. 69:101-107.

Doreau, M., and A. Ferlay. 1995. Effect of dietary lipids on nitrogen metabolism in the rumen: A review. Livest. Prod. Sci. 43:97-110.

Frutos, P., G. Hervás, F. J. Giráldez, and A. R. Mantecón. 2004. An in vitro study on the ability of polyethylene glycol to inhibit the effect of quebracho tannins and tannic acid on rumen fermentation in sheep, goats, cows and deer. Aust. J. Agric. Res. 55:1125-1132.

Garnsworthy, P. C. 1997. Fats in dairy cow diets. Pages 87-104 in Recent Advances in Animal Nutrition. P. C. Garnsworthy and J. Wiseman, ed. Nottingham Univ. Press, Nottingham, UK.

Gaynor, P. J., R. A. Erdman, B. B. Teter, J. Sampugna, A. V. Capuco, D. R. Wald, and M. Hamosh. 1994. Milk fat yield and composition during abomasal infusion of cis and trans octadecenoates in Holstein cows. J. Dairy Sci. 77:157-165.

Goering, M. K., and P. J. Van Soest. 1970. Forage Fiber Analysis (Apparatus, Reagents, Procedures and Some Applications). Agriculture Handbook No. 379. Agric. Res. Serv., US Dept. Agric., Washington, DC.

Griinari, J. M., and D. E. Bauman. 2006. Milk fat depression: Concepts, mechanisms and management applications. Pages 389417 in Ruminant Physiology: Digestion, Metabolism and Impact of Nutrition on Gene Expression, Immunology and Stress. K. Sjersen, T. Hvelplund, and M. O. Nielsen, ed. Wageningen Acad. Publ., Wageningen, the Netherlands. 
Griinari, J. M., D. A. Dwyer, M. A. McGuire, D. E. Bauman, D. L. Palmquist, and K. V. V. Nurmela. 1998. Trans-octadecenoic acids and milk fat depression lactating dairy cows. J. Dairy Sci. 81:1251-1261.

Harfoot, C. G., and G. P. Hazlewood. 1997. Lipid Metabolism in the Rumen. Pages 382-426 in The Rumen Microbial Ecosystem. P. M. Hobson, ed. Elsevier, New York, NY.

Hervás, G., P. Frutos, F. J. Giráldez, M. J. Mora, B. Fernández, and A. R. Mantecón. 2005. Effect of preservation on fermentative activity of rumen fluid inoculum for in vitro gas production techniques. Anim. Feed Sci. Technol. 123-124:107-118.

ISO-IDF. 2002. Milk Fat-Preparation of Fatty Acid Methyl Esters. International Standard ISO 15884-IDF 182:2002. International Organisation for Standardisation (ISO), Geneva, Switzerland.

Jenkins, T. C. 1993. Lipid metabolism in the rumen. J. Dairy Sci. 76:3851-3863.

Kraft, J., M. Collomb, P. Möckel, R. Sieber, and G. Jahreis. 2003. Differences in CLA isomer distribution of cows' milk lipids. Lipids 38:657-664.

Kucuk, O., B. W. Hess, P. A. Ludden, and D. C. Rule. 2001. Effect of forage:concentrate ratio on ruminal digestion and duodenal flow of fatty acids in ewes. J. Anim. Sci. 79:2233-2240.

Loor, J. J., A. Ferlay, A. Ollier, M. Doreau, and Y. Chilliard. 2005. Relationship among trans and conjugated fatty acids and bovine milk fat yield due to dietary concentrate and linseed oil. J. Dairy Sci. 88:726-740.

Luna, P., A. Bach, M. Juárez, and M. A. de la Fuente. 2008. Influence of diets rich in flax seed and sunflower oil on the fatty acid composition of ewes' milk fat especially on the content of conjugated linoleic acid, n-3 and n-6 fatty acids. Int. Dairy J. 18:99-107.

Luna, P., J. Fontecha, M. Juárez, and M. A. de la Fuente. 2005a. Changes in the milk and cheese fat composition of ewes fed commercial supplements containing linseed with special reference to the CLA content and isomer composition. Lipids 40:445-454.

Luna, P., M. Juárez, and M. A. de la Fuente. 2005b. Validation of a rapid milk fat separation method to determine the fatty acid profile by gas chromatography. J. Dairy Sci. 88:3377-3381.

Mauricio, R. M., F. L. Mould, M. S. Dhanoa, E. Owen, K. S. Channa, and M. K. Theodorou. 1999. A semi-automated in vitro gas production technique for ruminant feedstuff evaluation. Anim. Feed Sci. Technol. 79:321-330.
Mele, M., A. Buccioni, F. Petacchi, A. Serra, S. Banni, M. Antongiovanni, and P. Secchiari. 2006. Effect of forage/concentrate ratio and soybean oil supplementation on milk yield, and composition from Sarda ewes. Anim. Res. 55:273-285.

Nudda, A., M. A. McGuire, G. Battacone, and G. Pulina. 2005. Seasonal variation in conjugated linoleic acid and vaccenic acid in milk fat of sheep and its transfer to cheese and Ricotta. J. Dairy Sci. 88:1311-1319.

Palmquist, D. L., A. L. Lock, K. J. Shingfield, and D. E. Bauman 2005. Biosynthesis of conjugated linoleic acid in ruminants and humans. Adv. Food Nutr. Res. 50:179-217.

Piperova, L. S., J. Sampugna, B. B. Teter, K. F. Kalscheur, M. P. Yurawecz, Y. Ku, K. Morehouse, and R. A. Erdman. 2002. Duodenal and milk trans octadecenoic acid and conjugated linoleic acid (CLA) isomers indicate postabsorptive synthesis is the predominant source of cis-9 containing CLA in lactating dairy cows. J. Nutr. 132:1235-1241.

Pulina, G., A. Nudda, G. Battacone, and A. Cannas. 2006. Effects of nutrition on the contents of fat, protein, somatic cells, aromatic compounds, and undesirable substances in sheep milk. Anim. Feed Sci. Technol. 131:255-291.

SAS. 1999. SAS OnlineDoc. Version 8. SAS Inst. Inc., Cary, NC.

Shingfield, K. J., C. K. Reynolds, G. Hervás, J. M. Griinari, A. S. Grandison, and D. E. Beever. 2006. Examination of the persistency of milk fatty acid composition responses to fish oil and sunflower oil in the diet of dairy cows. J. Dairy Sci. 89:714-732.

Theodorou, M. K., B. A. Williams, M. S. Dhanoa, A. B. McAllan, and J. France. 1994. A simple gas production method using a pressure transducer to determine the fermentation kinetics of ruminant feeds. Anim. Feed Sci. Technol. 48:185-197.

Van Soest, P. J., J. B. Robertson, and B. A. Lewis. 1991. Methods for dietary fiber, neutral detergent fiber and non-starch polysaccharides in relation to animal nutrition. J. Dairy Sci. 74:35833597.

Wang, Z., and L. A. Goonewardene. 2004. The use of MIXED models in the analysis of animal experiments with repeated measures data. Can. J. Anim. Sci. 84:1-11.

Zhang, R. H., A. F. Mustafa, and X. Zhao. 2006. Effects of feeding oilseeds rich in linoleic and linolenic fatty acids to lactating ewes on cheese yield and on fatty acid composition of milk and cheese. Anim. Feed Sci. Technol. 127:220-233. 